\title{
GREEN BUILDING IMPLEMENTATION STUDY BASED ON EFICIENCY ENERGI in RUMAH JOGLO as DEVELOPMENT OF TEACHING MATERIALS COURSE PROGRAM AND PLANNING APPLICATION
}

\author{
Andini Dwi P', A.G. Thamrin ${ }^{2}$, Chundakus Habsya ${ }^{3}$ \\ Pendidikan Teknik Bangunan, Universitas Sebelas Maret \\ Email: adwip222@gmail.com
}

\begin{abstract}
This research was purposed to knowing (1) the implementation of green building on aspect natural lighting in Rumah Joglo terms of SNI 03-6197-2000; (2) the implementation of green building on aspect natural ventilation in Rumah Joglo terms SNI 03-6572-2001; (3) the implementation of green building in Rumah Joglo for development of teaching materials course Program and Planning Application in PTB FKIP UNS. This research was conducted by measuring the natural lighting, air velocity, relative huminidity, and air temperature in each room in the Rumah Joglo as well as the occupants questionnaire provide. The subjects were five Rumah Joglo. The result showed that $89,74 \%$ of natural lighting in the research subjects does not meet the requirements of SNI 03-6197-2000, 82,25\% of air velocity does not meet the requirements of SNI 03-6572-2001, for relative huminidity and air temperature in the object of study does not meet the requirements of SNI 03-6572-2001. The result of this research can be use for development of teaching materials course Program and Planning Application in PTB UNS.
\end{abstract}

Keyword: Joglo, Natural Lighting, Natural Ventilation

\footnotetext{
${ }^{1}$ Mahasiswa Program Studi Pendidikan Teknik Bangunan FKIP UNS.

${ }^{2}$ A. G. Thamrin

${ }^{3}$ Chundakus Habsya
} 


\section{PENDAHULUAN}

Rumah tinggal merupakan salah satu kebutuhan hidup yang utama disamping kebutuhan sandang dan pangan. Rumah tinggal mempunyai peran sebagai wadah kegiatan bagi penghuninya dalam menjalankan kehidupan sehari-hari. Sebagai salah satu kebutuhan primer dan mempunyai peranan penting dalam siklus hidup manusia, dalam perencanaannya, rumah tinggal hendaknya direncanakan secara cermat.

Salah satu yang menjadi pertimbangan dalam perencanaan sebuah hunian atau rumah tinggal yaitu perencanaan yang memperhatikan kondisi lingkungan sekitar, seperti kondisi geologis, iklim setempat dan bahan bangunan, serta prinsip pembangunan yang sekecil mungkin merusak alam. Apabila hal ini diterapkan, akan menciptakan hunian yang nyaman sekaligus membawa dampak positif untuk kelestarian lingkungan.

Hunian yang nyaman dan bisa memberikan nilai positif untuk kelestarian lingkungan, bisa diwujudkan melalui rumah tinggal berkonsep bangunan ramah lingkungan (green building). Dalam peraturan menteri pekerjaan umum dan perumahan rakyat pebulik Indonesia No. 02 tahun 2015, menjelaskan bahwa:

Green building adalah bangunan gedung yang memenuhi persyaratan dan memiliki kinerja terukur secara signifikan dalam penghematan energi, air dan sumber daya lainnya melalui penerapan prinsip bangunan gedung hijau sesuai dengan fungsi dan klasifikasi dalam tahapan penyelenggaraannya.

Kriteria green building yang bisa diterapkan dalam perencanaan rumah tinggal adalah Efisiensi dan Konservasi Energi (EEC). EEC bertujuan untuk mendorong penghematan energi melalui langkah-langkah efisiensi energi. Berdasarkan penjelasan Prihantanto Setyohadi (2011), bahwa komponen distribusi penggunaan energi yang terbesar pada sebuah bangunan gedung adalah pada sistem alat pendingin ruangan yaitu $50-70 \%$, kemudian pencahayaan dengan energi listrik sebesar 10 - 25\%. Oleh sebab itu sasaran penghematan energi dalam pembangunan gedung lebih ditujukan pada optimalisasi sistem tata udara dan tata cahaya.

Pada rumah tinggal, sistem tata cahaya dan sistem tata udara merupakan komponen yang memainkan peranan penting. Untuk mengoptimalkan kedua

\footnotetext{
${ }^{1}$ Mahasiswa Program Studi Pendidikan Teknik Bangunan FKIP UNS

${ }^{2}$ A. G. Thamrin

${ }^{3}$ Chundakus Habsya
} 
sistem tersebut, diperlukan perencanaan yang tepat, perencana atau pemilik rumah bisa menerapkan sistem pencahayaan dan penghawaan alami. Dengan menerapkan pencahayaan dan penghawaan alami pemilik rumah bisa memangkas kebutuhan energi listrik.

Hidup di negara Indonesia yang merupakan negara khatulistiwa, menjadikan Indonesia memiliki iklim tropis panas lembab. Hal ini bisa menjadi acuan bagi perencana maupun pemilik rumah dalam mendesian rumah tinggal.

Sekarang ini banyak sekali referensi desain rumah tinggal yang mungkin bisa dijadikan ide dalam mendesian, salah satunya adalah rumah tradisional. Indonesia memiliki beragam rumah tradisional yang tersebar dari Sabang hingga Merauke. Rumah tradisional Indonesia juga dipercaya sebagai bangunan yang responsif terhadap iklim setempat. Alfata (2015), menjelaskan bahwa bangunan tradisional mampu memberikan kenyamanan termal bagi penggunanya dengan pemakaian energi yang minimum.

Dari berbagai bentuk rumah tradisional, Rumah Joglo bisa dijadikan ide dalam mendesain sebuah hunian.
Rumah Joglo merupakan salah satu tipe rumah tradisional Jawa. Rumah Joglo pada masanya merupakan bangunan yang dimiliki oleh kaum bangsawan. Tipe ini dipilih untuk membangun unit bangunan tertentu saja, yaitu Pendhapa dan Dalem.

Dalam proses perwujudannya, rumah tradisional jawa dipengaruhi oleh beberapa faktor, salah satu diantaranya adalah diwujudkan dengan bersendikan lingkungan dan konsmologi. Sunarmi (2007), menjelaskan bahwa pertimbangan lokasi, bahan konstruksi dan bentuk pada dasarnya didasarkan pada kecerdasan kemampuan dalam mencermati sifat alam, walaupun dalam praktiknya didasari keyakinan bahwa adanya dampak dari pertimbangan tersebut. Sebagai contoh, pencermatan pada kebiasaan cara tumbuh kayu dijadikan dasar untuk menentukan pemilihan kayu yang berkualitas.

Masyarakat Jawa dengan faham kejawen juga sering dianggap oleh kalangan lain sebagai masyarakat yang hidup dalam suasana kepercayaan primitif, walaupun sebenarnya dengan faham itulah mereka kemudian dikatakan mempunyai sifa-sifat khusus. Arya Ronald (2007), menjelaskan bahwa hal yang tampak khusus adalah

\footnotetext{
${ }^{1}$ Mahasiswa Program Studi Pendidikan Teknik Bangunan FKIP UNS.

${ }^{2}$ A. G. Thamrin

${ }^{3}$ Chundakus Habsya
} 
cara mempertahankan suasana hidup selaras dengan kehidupan lingkungan di sekitarnya.

Pengkajian lebih lanjut mengenai rumah tradisional jawa khususnya rumah Joglo sudah sepatutunya dilaksanakan. Dalam penelitian ini, peneliti mengkaji implementasi green building berdasarkan kriteria efisiensi energi pada rumah Joglo. Aspek yang menjadi fokus penelitian adalah sistem pencahayaan alami dan penghawaan alami pada rumah Joglo.

Tujuan yang ingin dicapai pada penelitian ini adalah sebagai berikut:

- Untuk mengetahui implementasi green building berdasarkan kriteria efisiensi energi pada aspek pencahayaan alami di rumah Joglo ditinjau dari SNI 03-6197-2000.

- Untuk mengetahui implementasi green building berdasarkan kriteria efisiensi energi pada aspek penghawaan alami di rumah Joglo ditinjau dari SNI 03-6572-2001.

- Untuk mengetahui implementasi green building berdasarkan kriteria efisiensi energi padar umah Joglo, digunakan sebagai suplemen bahan ajar mata kuliah Aplikasi Perencanaan dan Perancangan di prodi Pendidikan Teknik

Bangunan, FKIP, UNS.

\section{METODOLOGI PENELITIAN}

Tempat penelitian dilakukan di rumah tinggal yang berbentuk rumah Joglo berjumlah lima rumah. Penelitian ini merupakan jenis penelitian yang menggunakan pendekatan kuantitatif. Metode yang digunakan pada penelitian ini adalah metode kuantitatif deskriptif. Menurut Sugiono (2009:14), metode kuantitatif deskriptif diartikan sebagai metode penelitian yang berlandaskan pada filsafat positivisme, digunakan untuk meneliti populasi atau sampel tertentu, teknik pengambilan sampel pada umumnya random, pengumpulan data menggunakan instrumen penelitian, analisis data bersifat kuantitatif/ statistik, dengan tujuan untuk menguji hipotesis yang telah ditetapkan.

Populasi dalam penelitian ini adalah rumah tradisional jawa. Teknik pengambilan sampe menggunakan teknik purposive samling, sampel pada penelitian ini adalah rumah joglo berjumlah lima rumah.

Teknik pengumpulan data pada penelitian ini adalah Observasi, Instrumen yang terdiri dari kuisioner (angket), pengukuran pencahayaan alami menggunakan Light Meter,

\footnotetext{
${ }^{1}$ Mahasiswa Program Studi Pendidikan Teknik Bangunan FKIP UNS.

${ }^{2}$ A. G. Thamrin

${ }^{3}$ Chundakus Habsya
} 
pengukuran penghawaan alami menggunakan 4 in 1 Envirometer, dan dokumentasi.

Teknik uji yang digunakan untuk kuisioner adalah:

1. Uji validitas instrumen

Uji validitas instrumen dilakukan dengan menggunakan korelasi person dalam program Microsoft Office Excel 2007, menggunakan rumus:

$R_{x y}=$

$\frac{n\left(\sum x y\right)-\left(\sum x\right)\left(\sum y\right)}{\sqrt{\left[n\left(\sum x^{2}\right)-\left(\sum x\right)^{2}\right]\left[n\left(\sum y^{2}\right)-\left(\sum y\right)^{2}\right]}}$

dimana:

$\mathrm{r}_{\mathrm{xy}}=$ koefisien korelasi suatu butir/ item

$\mathrm{n}=$ jumlah subyek

$\mathrm{x}=$ skor suatu butir/ item

$\mathrm{y}=$ skor total

2. Uji reliabilitas instrumen

Uji reliabilitas instrumen dilakukan dengan metode Alpha Cronbrach dalam program Microsoft Office Excel 2007 dengan taraf kesalahan $5 \%$ dengan rumus:

$r_{11}=\left[\frac{k}{k-1}\right]\left[1-\frac{\sum \sigma_{b}^{2}}{v_{t^{2}}}\right]$

dimana:

$\mathrm{r}_{11}=$ reabilitas instrument

$\mathrm{k}$ = banyaknya butir pertanyaan

$\sigma_{b^{2}}=$ jumlah varian butir/ item

$v_{t^{2}}=$ varian total
Analisis data yang pada penelitian ini adalah statistik deskriptif, digunakan untuk mengetahui memnuhi persyaratan atau tidak pencahayaan alami ditinjau dari SNI 03-6197-2000 dan penghawaan alami ditinjau dari SNI 036572-2001. Hasil dari kuisioner digunakan untuk mengetahui kenyamanan dalam ruangan menurut persepsi pemilik/ pengguna rumah.

Teknik penelitian analisis isi digunakan untuk mengetahui bisa tidaknya hasil penelitian digunakan sebagai suplemen bahan ajar mata kuliah Aplikasi Perencanaan dan Perancangan (APP). Sumber data penelitian yaitu data primer berupa Rencana Pembelajaran Semester (RPS) mata kuliah APP dan data sekunder berupa hasil penelitian.

HASIL PENELITIAN DAN

\section{PEMBAHASAN}

1. Hasil Penelitian

Tabel 1. Rekapitulasi Data Hasil Pengukuran Pencahayaan Alami

\begin{tabular}{|c|c|c|c|c|c|}
\hline \multirow{2}{*}{$\begin{array}{l}\text { Fungsi } \\
\text { Ruang }\end{array}$} & \multicolumn{5}{|c|}{ 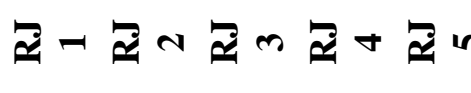 } \\
\hline & \multicolumn{5}{|c|}{$\begin{array}{c}\text { Hasil pengukuran } \\
\text { Pencahayaan Alami (lux) }\end{array}$} \\
\hline R. Tamu & 156 & 119 & 61 & 74 & 84 \\
\hline R. Kelg & 32 & 160 & & 33 & 172 \\
\hline R. Makan & 42 & & 50 & 31 & 239 \\
\hline R. Tidur 1 & 210 & 156 & & & 26 \\
\hline R. Tidur 2 & & 160 & & & 55 \\
\hline Dapur & 243 & 283 & 35 & 63 & 52 \\
\hline
\end{tabular}

${ }^{1}$ Mahasiswa Program Studi Pendidikan Teknik Bangunan FKIP UNS.

${ }^{2}$ A. G. Thamrin

${ }^{3}$ Chundakus Habsya 
Keterangan:

RJ = Rumah Joglo

$=$ Ruangan yang tidak tersedia

Tabel 2. Rekapitulasi data hasil pengukuran suhu dan kelembapan udara pada rumah joglo

\begin{tabular}{lcc}
\hline $\begin{array}{c}\text { Fungsi } \\
\text { Ruang }\end{array}$ & Suhu $\left({ }^{\mathbf{0}} \mathbf{C}\right)$ & $\begin{array}{c}\text { Kelembapan } \\
(\boldsymbol{\%})\end{array}$ \\
\hline R. Tamu & $29,5-28,1$ & $72,8-70,2$ \\
\hline R. Kelg & $29,7-28,3$ & $70,8-72,3$ \\
\hline R. Makan & 30,0 & 72,6 \\
\hline R. Tidur 1 & $30,0-28,4$ & $69,3-75,1$ \\
\hline R. Tidur 2 & 28,2 & 75,5 \\
\hline Dapur & $30,3-28,6$ & $65,4-73,5$ \\
\hline
\end{tabular}

Tabel 3. Rekapitulasi data hasil pengukuran kecepatan angin pada rumah joglo

\begin{tabular}{|c|c|c|c|c|c|}
\hline \multirow{2}{*}{$\begin{array}{l}\text { Fungsi } \\
\text { Ruang }\end{array}$} & \multicolumn{5}{|c|}{ 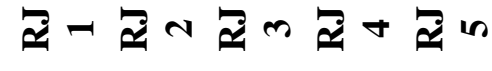 } \\
\hline & \multicolumn{5}{|c|}{$\begin{array}{c}\text { Hasil pengukuran } \\
\text { kecepatan angin }(\mathrm{m} / \mathrm{s})\end{array}$} \\
\hline R. Tamu & $\begin{array}{c}0,0- \\
1,2\end{array}$ & $\begin{array}{l}0,0- \\
0,4\end{array}$ & $\begin{array}{c}0,0- \\
0,5\end{array}$ & $\begin{array}{c}0,0- \\
0,4\end{array}$ & $\begin{array}{c}0,0- \\
0,9\end{array}$ \\
\hline R. Kelg & $\begin{array}{c}0,0- \\
1,3\end{array}$ & $\begin{array}{l}0,0- \\
0,3\end{array}$ & & 0,0 & $\begin{array}{c}0,0- \\
0,2\end{array}$ \\
\hline R. Makan & $\begin{array}{c}0,0- \\
0,5\end{array}$ & & 0,0 & 0,0 & 0,0 \\
\hline R. Tidur 1 & 0,0 & $\begin{array}{l}0,0- \\
0,5\end{array}$ & & & 0,0 \\
\hline R. Tidur 2 & & 0,0 & & & $\begin{array}{c}0,0- \\
0,1\end{array}$ \\
\hline Dapur & $\begin{array}{c}0,0- \\
0,2\end{array}$ & $\begin{array}{c}0,0- \\
1,0\end{array}$ & $\begin{array}{c}0,0- \\
0,4\end{array}$ & $\begin{array}{c}0,0- \\
0,2\end{array}$ & 0,0 \\
\hline
\end{tabular}

Keterangan:

RJ = Rumah Joglo

$=$ Ruangan yang tidak tersedia
2. Pembahasan

Pengukuran pencahayaan alami dilakukan dengan tiga waktu pengukuran, yaitu pagi, siang dan sore hari. Setelah diperoleh data hasil pegukuran pencahayaan alami pada rumah Joglo 1s/d 5, kemudian dianalisa sesuai dengan persyaratan SNI 03-6197-2000, persyaratan pencahayaan alami untuk rumah tinggal adalah sebagai berikut:

Tabel 4. Persyaratan pencahayaan alami pada rumah tinggal

\begin{tabular}{cc}
\hline Fungsi Ruang & $\begin{array}{c}\text { Tingkat } \\
\text { Pencahayaan } \\
\text { (lux) }\end{array}$ \\
\hline R. Tamu & $120-150$ \\
\hline R. Makan & $120-250$ \\
\hline R. Tidur & $120-250$ \\
\hline Dapur & 250 \\
\hline
\end{tabular}

Secara umum, pencahayaan alami pada rumah Joglo relatif stabil dari pagi hari hingga sore hari. Tetapi ada beberapa ruang yang menunjukkan tingkat intensitas pencahayaan alami yang rendah dan relatif lebih tinggi daripada yang disyaratkan dalam SNI 03-6197-2000, seperti yang ditunjukkan pada tabel 1 .

Rendahnya intensitas cahaya alami pada rumah Joglo disebabkan oleh:

\footnotetext{
${ }^{1}$ Mahasiswa Program Studi Pendidikan Teknik Bangunan FKIP UNS.

${ }^{2}$ A. G. Thamrin

${ }^{3}$ Chundakus Habsya
} 
a. Minimnya bidang bukaan atau bidang tertutup transparan pada bangunan,

b. Dimensi tritisan yang lebar pada teras menyebabkan cahaya matahari tidak dapat masuk secara merata dalam ruangan,

c. Tata letak ruangan yang kurang menguntungkan, yaitu terdapat ruang di dalam ruang lain yang sehingga tidak memungkinkan untuk tersedianya bukaan yang menghubungkan langsung pada lingkungan luar rumah.

Terlepas dari rendahnya intensitas pencahayaan alami, terdapat beberapa ruangan pada rumah Joglo, tingkat pencahayaan alami memenuhi persyaratan SNI 03-6197-2000, faktor-faktor pendukung terpenuhinya pencahayaan alami dalam ruang adalah:

a. Pemanfaatan skylight yaitu genting transparan pada atap, namun tetap memperhatikan posisi perletakkannya, sehingga cahaya yang dihasilkan tidak terlampau terang.

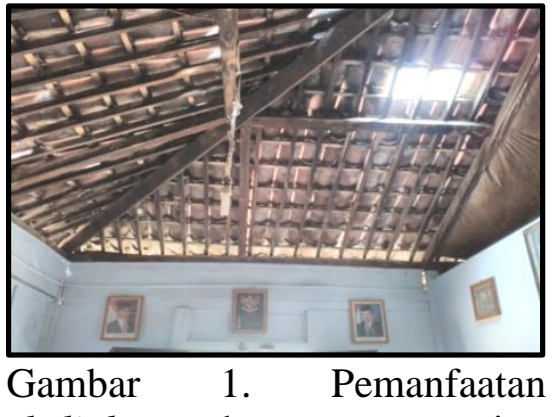
skylight berupa genting transparan untuk memasukkan cahaya matahari melalui atap bangunan.

b. Orientasi bangunan atau arah hadap bangunan. Seperti pada rumah Joglo 2 yang memiliki orientasi bangunan ke arah utara, ruang tidur bisa ditempat pada sisi timur dan bukaan (jendela) bisa diarahkan ke arah timur, sehingga manfaat cahaya matahari pagi bisa masuk ke dalam ruang.

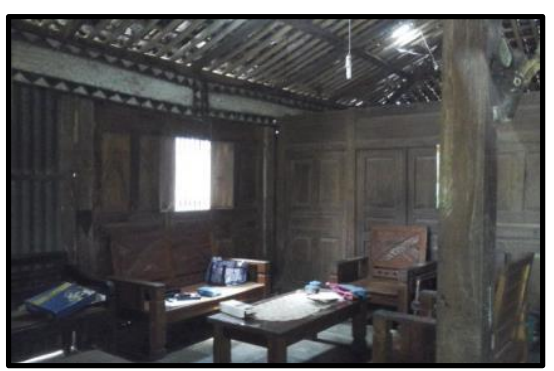

Gambar 2. Orientasi bukaan (jendela) yang mengarah ke timur, intensitas cahaya lebih stabil dari pagi hingga siang hari.

Untuk ruang-ruang service seperti dapur dan kamar mandi bisa ditempatkan pada sisi barat, dapur dan kamar mandi

\footnotetext{
${ }^{1}$ Mahasiswa Program Studi Pendidikan Teknik Bangunan FKIP UNS.
}

${ }^{2}$ A. G. Thamrin

${ }^{3}$ Chundakus Habsya 
membutuhkan cahaya matahari dengan radiasi yang sedikit lebih tinggi daripada ruang lainnya, hal ini berfungsi untuk mencegah pertumbuhan jamur.

c. Tersedianya ruang terbuka pada bangunan. Ruang terbuka pada bangunan bermanfaat untuk mengoptimalkan pencahayaan alami dan juga menunjang dalam sirkulasi udara pada rumah tinggal

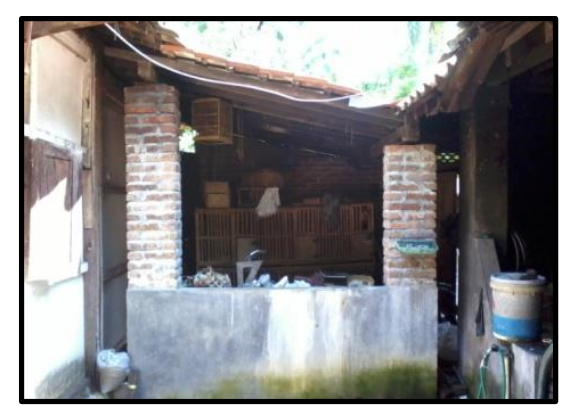

Gambar 3. Ruang Terbuka pada rumah Joglo 1

Penghawaan alami pada rumah Joglo diukur dengan menggunakan 4 in 1 Envirometer, yaitu kecepatan angin, kelembapan udara dan suhu dalam ruangan. Hasil dari pengukuran, dianalisis berdasarkan persyaratan SNI 036572-2001. Kriteria kecepatan angin, kelembapan udara dan suhu dalam ruangan adalah:

$$
\begin{aligned}
& \text { Kecepatan udara : } \quad 0,15- \\
& 0,25 \mathrm{~m} / \mathrm{s}
\end{aligned}
$$

$>$ Kelembapan udara : $40-50 \%$

$>$ Temperatur (suhu) :

- Sejuk nyaman $: 20,5^{\circ} \mathrm{C}-$ $22,8^{0} \mathrm{C}$

- Nyaman optimal : $22,8^{0} \mathrm{C}$ $-25,8^{0} \mathrm{C}$

○ Hangat optimal : $25,8^{0} \mathrm{C}$ $27,1^{0} \mathrm{C}$

Berdasarkan hasil analisis data penghawaan alami ditinjau berdasarkan persyaratan SNI 036572-2001, menunjukkan bahwa objek penelitian yaitu lima rumah joglo, penghawaan alami pada sebagian besar ruang tidak memenuhi persyaratan SNI 036572-2001.

Seperti yang tertera pada tabel 2, suhu udara dalam ruang lebih dari $27,1^{\circ} \mathrm{C}$, yang mana suhu tersebut adalah batas maksimal suhu ruang untuk kategori hangat optimal. Tingginya suhu dalam ruang disebabkan oleh minimnya bidang bukaan pada bangunan, yang mengakibatkan ventilasi silang (cross ventilation) tidak bekerja optimal.

Ventilasi yang tidak berjalan dengan optimal, juga menyebabkan kelembapan dalam ruang tinggi, tabel 2 menunjukkan bahwa

\footnotetext{
${ }^{1}$ Mahasiswa Program Studi Pendidikan Teknik Bangunan FKIP UNS.

${ }^{2}$ A. G. Thamrin

${ }^{3}$ Chundakus Habsya
} 
kelembapan udara dalam ruang bisa mencapai $70 \%$, hasil ini tentunya tidak sesuai dengan persyaratan SNI 03-6572-2001 yaitu 40-50\%.

Tabel 3 menunjukkan kecepatan angin dalam masingmasing ruang pada rumah joglo. Secara umum kecepatan angin dalam ruang pada rumah Joglo tidak memenuhi persyaratan SNI 03-6572-2001. Sebagai contoh kecepatan angin pada rumah Joglo 4 yang ditunjukkan pada gambar 4 .

\begin{tabular}{|c|c|}
\hline \multicolumn{2}{|c|}{$\begin{array}{l}\text { Kecepatan } \\
\text { Angin }(\mathrm{m} / \mathrm{s})\end{array}$} \\
\hline & \\
\hline 0.2 & 0.2 \\
\hline 0.00 .00 .00 .0 & $0.00 .00 .0 \quad 0.00 .00 .0^{0.1}$ \\
\hline
\end{tabular}

Gambar 4. Diagram kecepatan angin pada rumah Joglo 4

Gambar 4 menunjukkan bahwa pada pagi hari kecepatan angin yang terukur adalah $0,0 \mathrm{~m} / \mathrm{s}$, pada siang hari $0,2 \mathrm{~m} / \mathrm{s}-0,4 \mathrm{~m} / \mathrm{s}$, sedangkan pada sore hari $0,0 \mathrm{~m} / \mathrm{s}-$ $0,1 \mathrm{~m} / \mathrm{s}$.

Kecepatan angin yang tidak konstan dan rendahnya kecepatan angin di beberapa ruang pada rumah Joglo disebabkan oleh minimnya bidang bukaan pada bangunan, dan tata letak ruang yang kurang menguntungkan. Seperti yang ditunjukkan pada gambar 5 .

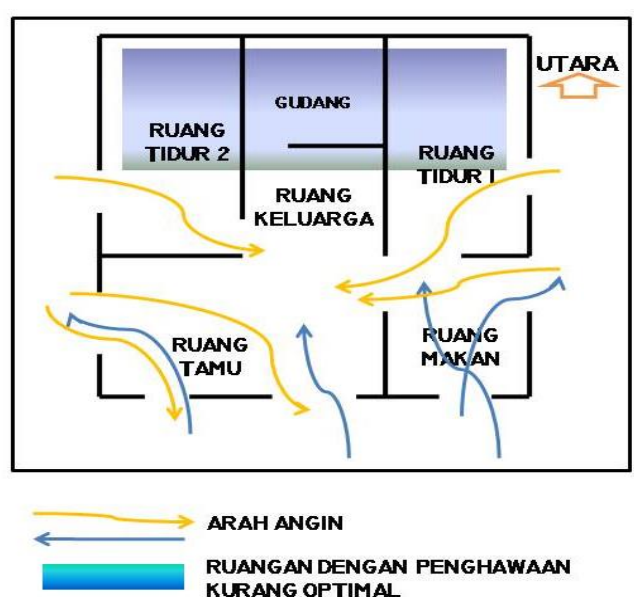

Gambar 5. Ruangan yang tidak memiliki bidang bukaan penghawaan alami cenderung kurang optimal.

3. Penelitian Analisis Isi

Teknik analisis isi digunakan untuk mengetahui bisa tidaknya hasil penelitian digunakan sebagai suplemen bahan ajar mata kuliah Aplikasi Perencanaan dan Perancanagan.

Berdasarkan

Rencana Pembelajaran Semester (RPS) mata kuliah Aplikasi Perencanaan dan Perancangan, memiliki keterkaitan dengan hasil penelitian, sehingga hasil penelitian dapat digunakan untuk suplemen bahan ajar mata kuliah APP.

Keterkaitan hasil penelitian dengan RPS mata kuliah aplikasi

\footnotetext{
${ }^{1}$ Mahasiswa Program Studi Pendidikan Teknik Bangunan FKIP UNS.

${ }^{2}$ A. G. Thamrin

${ }^{3}$ Chundakus Habsya
} 
perencanaan dan perancangan

adalah sebagai berikut:

Tabel 5. Hasil Penelitian Analisis Isi

\begin{tabular}{|c|c|c|}
\hline $\begin{array}{l}\text { Materi } \\
\text { Pokok }\end{array}$ & Indikator & $\begin{array}{c}\text { Hasil } \\
\text { Penelitian }\end{array}$ \\
\hline $\begin{array}{l}\text { Menggambar } \\
\text { tapak dengan } \\
\text { empertimban } \\
\text { gkan } \\
\text { kebutuhan } \\
\text { pencahayaan, } \\
\text { penghawaan } \\
\text { alami }\end{array}$ & $\begin{array}{l}\text { Dapat } \\
\text { membuat } \\
\text { denah tugas } \\
\text { proyek; } \\
\text { ruang- } \\
\text { ruang } \\
\text { terbentuk } \\
\text { efisien } \\
\text { sesuai } \\
\text { fungsi, } \\
\text { hubungan } \\
\text { ruang } \\
\text { fungsional }\end{array}$ & $\begin{array}{l}\text { - Pencahaya } \\
\text { an alami } \\
\text { - Penghawaa } \\
\text { n alami } \\
\text { - Orientasi } \\
\text { bangunan } \\
\text { - Tata letak } \\
\text { (layout) } \\
\text { ruangan }\end{array}$ \\
\hline $\begin{array}{l}\text { Kaidah } \\
\text { estetika } \\
\text { bangunan, } \\
\text { fungsi } \\
\text { komponen } \\
\text { bangunan }\end{array}$ & $\begin{array}{l}\text { Minimal } 2 \\
\text { gambar } \\
\text { tampak } \\
\text { bangunan } \\
\text { yang estetis }\end{array}$ & $\begin{array}{l}\text { - Arsitektur } \\
\text { tradisional } \\
\text { - Rumah } \\
\text { Tradisional } \\
\text { Jawa } \\
\text { tengah } \\
\text { - Rumah } \\
\text { Joglo }\end{array}$ \\
\hline
\end{tabular}

\section{KESIMPULAN DAN SARAN}

1. Simpulan

Setelah melakukan analisis pencahayaan alami dan penghawaan alai pada rumah Joglo, maka dapat disimpulkan:

a. Implementasi green building berdasarkan kriterian efisiensi energi pada aspek pencahayaan alami tidak memenuhi persyaratan SNI 03-6197-2000.

b. Implementasi green building berdasarkan kriteria efisiensi energi pada aspek penghawaan alami tidak memenuhi persyaratan SNI 03-6572-2001.

c. Hasil penelitian dapat digunakan sebagai suplemen bahan ajar mata kuliah Aplikasi Perencanaan dan Perancangan.

2. Saran

Berdasarkan hasil pembahasan dan simpulan penelitian dapat diajukan saransaran sebagai berikut:

a. Perlu diadakan penelitian yang lebih lanjut mengenai implementasi green building pada bangunan tradisional Indonesia.

b. Untuk penelitian selanjutnya, dianjurkan untuk melakukan penelitian implementasi green building berdasarkan kriteria yang lebih bervariatif,

c. Melakukan penelitian lebih lanjut mengenai rumah tradisional jawa.

d. Untuk penelitian selanjutnya, penelitian pencahayaan dan penghawaan alami dianjurkan dilakukan pada dua musim, dengan tujuan data yang dihasilkan lebih akurat.

${ }^{1}$ Mahasiswa Program Studi Pendidikan Teknik Bangunan FKIP UNS.

${ }^{2}$ A. G. Thamrin

${ }^{3}$ Chundakus Habsya 


\section{DAFTAR PUSTAKA}

Badan Standarisasi Nasional. (2000). SNI 03-6197-2000 Konservasi Energi Pada Sistem Pencahayaan.

Badan Standarisasi Nasional. (2001). SNI 03-6572-2001 Tata Cara Perancangan Sistem Ventilasi dan Pengkondisian Udara Pada Bangunan Gedung.

Frick, H., \& Mulyani, T. H. (2012). Arsitektur Ekologis. Yogyakarta: Kanisius.

Ismunandar K, R. (2007). JOGLO Arsitektur Rumah Tradisional Jawa. Semarang: Dahara Prize.

Karyono, T. H. (2010). Green Architecture Pengantar Pemahaman Arsitektur Hijau di Indonesia. Jakarta: Rajawali Pers.

Latifah, N. L. (2015). Fisika Bangunan 1. Jakarta: Griya Kreasi.

Mediastika, C. E. (2013). Hemat Energi dan Lestari Lingkungan Melalui Bangunan. Yogyakarta: ANDI.

Peraturan Menteri Pekerjaan Umum dan Perumahan Rakyat Republik Indonesia. (2015). Bangunan Gedung Hijau. Retrieved September 7, 2015, from http://birohukum.pu.go.id/uploads /DPU/2015/PermenPUPR022015.pdf

Ronald, A. (2005). Nilai-Nilai Arsitektur Rumah Tradisional Jawa. Yogyakarta: Gadjah Mada University Press.

Sugiono. (2010). Metode Penelitian Pendidikan. Bandung: Alfabeta.
Sunarmi, Guntur, \& Utomo, T. P. (2007). Arsitektur dan Interior Nusantara Seri Jawa. Surakarta: ISI Surakarta dan UNS Press. 